\title{
The co-management of the sand eel fishery of Catalonia (NW Mediterranean): the story of a process
}

\author{
Jordi Lleonart ${ }^{1}$, Montserrat Demestre ${ }^{1}$, Paloma Martín ${ }^{1}$, Jordi Rodón ${ }^{2}$, Susana Sainz-Trápaga ${ }^{3}$, \\ Pilar Sánchez ${ }^{1}$, Itziar Segarra ${ }^{2}$, Sergi Tudela ${ }^{3}$ \\ ${ }^{1}$ Institut de Ciències del Mar de Barcelona, CSIC, Passeig Marítim de la Barceloneta, 37-49, 08003 Barcelona, Spain. \\ E-mail: lleonart@icm.csic.es \\ ${ }^{2}$ Direcció General de Pesca i Afers Marítims de la Generalitat de Catalunya, Gran Via de les Corts Catalanes, 612-614, \\ 08007 Barcelona, Spain. \\ ${ }^{3}$ WWF Mediterranean Initiative. Canuda, 37, 08002 Barcelona, Spain.
}

\begin{abstract}
Summary: A management plan for the boat seines, called sonsera, used in Catalonia to target sand eels (Gymanammodytes cicerelus and G. semisquamatus) and transparent gobies was drawn up in accordance with European Union rules. A Sand Eel Co-Management Committee was formally created with the specific mission of ensuring a sustainable fishery. The Committee is composed of public administrations, fishermen's associations, researchers and NGOs. The process has two phases: first, a comprehensive study of the fishery and subsequent advice for the establishment of a management plan and, second, the implementation and monitoring of the management plan. The study of the fishery included the analysis of the ecosystem impacts of the fishery (mainly stock status, impact on sensitive habitats and by-catch) and was carried out in the wider context of an adaptive co-management process to respond to the requirements of an ecosystem approach to fisheries.
\end{abstract}

Keywords: fisheries co-management; small scale fisheries; sand eel; boat seine; Mediterranean Sea.

La cogestión de la pesquería de lanzón en Cataluña (NW del Mediterráneo): historia del proceso

Resumen: Se ha desarrollado un plan de gestión de acuerdo a las normas de la Unión Europea de la pesquería con arte de tiro desde embarcación, llamado "sonsera", que se utiliza en Cataluña para la pesca del lanzón (Gymanammodytes cicerelus y G. semisquamatus) y también de pequeños góbidos. Se creó formalmente un Comité de Cogestión con la misión específica de garantizar una pesca sostenible. El Comité está integrado por las administraciones públicas, asociaciones de pescadores, investigadores y organizaciones no gubernamentales. El proceso consta de dos fases: en primer lugar, un estudio exhaustivo de la pesquería y posterior asesoramiento para el establecimiento de un plan de gestión, y en segundo lugar, la aplicación y seguimiento del plan de gestión. El estudio de la pesquería ha incluido el análisis de los impactos ambientales de la pesca (principalmente el estado del stock, el impacto en hábitats sensibles y las capturas accesorias) y se ha llevado a cabo en el contexto más amplio de un proceso adaptativo de gestión conjunta para responder a los requisitos de un enfoque ecosistémico de la pesca.

Palabras clave: cogestión de pesquerías; pesquerías artesanales; lanzón; sonso; arte de tiro; mar Mediterráneo

Citation/Como citar este artículo: Lleonart J., Demestre M., Martín P., Rodón J., Sainz-Trápaga S., Sánchez P., Segarra I., Tudela S. 2014. The co-management of the sand eel fishery of Catalonia (NW Mediterranean): the story of a process. In: Lleonart J., Maynou F. (eds), The Ecosystem Approach to Fisheries in the Mediterranean and Black Seas. Sci. Mar. 78S1: 87-93. doi: http://dx.doi.org/10.3989/scimar.04027.25A

Editor: Francesc Maynou.

Received: October 28, 2013. Accepted: January 10, 2014. Published: March 28, 2014.

Copyright: (C) 2014 CSIC. This is an open-access article distributed under the Creative Commons Attribution-Non Commercial Lisence (by-nc) Spain 3.0.

\section{INTRODUCTION}

The family Ammodytidae includes 23 species distributed around the world (Nelson 2006). They are small, short-lived forage fish typically found on shallow sandy bottoms, usually burrowing into the sand.
Sand eel was used to "feed poor people" in the 18th century (Bomare 1764), but also as bait (Bomare 1800, uses the synonym appat de vase). In the North Atlantic and other seas sand eels are at present caught by industrial fleets for bait, meal, oil and fertilizer purposes (Reay 1970). In the Mediterranean sand eels are object 
of a small scale fishery mainly addressed to human consumption, documented at least since the beginning of the 19th century (Delaroche 1809). Sand eel was used as live bait by longliners in Catalonia (NW Mediterranean) in the mid-20th century (Bas et al. 1955).

Sand eels are well known in Catalonia, receiving the common names of sonso, enfú, trencavits and barrinaire, and their capture is a traditional activity for small-scale fleets. Delaroche (1809) reported sand eel (as Ammodytes tobianus) to be present in the Barcelona fish market. After Delaroche's paper, sand eel related to fisheries was cited in the works by Sánchez-Comendador (1904), Gibert (1913), Borja y Goyeneche (1920) and Lleó (1923).

Sand eels are target of a fishery carried out by a special boat seine called sonsera, (plural sonseres), which is the name of both gear and boat. Lleó (1923) reported the presence of 18 sonseres in Catalonia in 1920. According to Lleonart (Coord.) (1990) the number of sonseres in 1988 was 20. Further data about the fishery are found in Bas et al. (1955), and Sánchez and Demestre (1988). Currently 26 boats are entitled to use this gear, distributed in 6 ports of the central and northeast coast of Catalonia.

There are two species of sand eel in Catalonia: Gymnammodytes cicerelus (Mediterranean sand eel, sonso blau in Catalan), by far the most abundant species, and Gymnammodytes semisquamatus (smooth sand eel, sonso ros in Catalan). The taxonomy of these species was unsure in the past (Ammodytes tobianus was used as a synonym of G. semisquamatus by several sources, as in Fischer et al. 1987), but eventually the identification of the species present in Catalonia was solved by Sabatés et al. (1990). Individuals of both species rarely reach $15 \mathrm{~cm}$ length and they live on shallow sandy bottoms (between 5 and $10 \mathrm{~m}$ depth). Their catches are used for human consumption, and a very small proportion for bait. Sand eels are consumed fresh. In the period 2000-2012 prices ranged between 1 and $5 € / \mathrm{kg}$, with a mean of $2 € / \mathrm{kg}$. The price increased to $3.5 € / \mathrm{kg}$ in 2013 , the highest annual mean on record.

Boats operate on a daily trip basis, going to fish five days a week early in the morning when sand eels leave their holes. Fishers search for schools using echo sounding, and after one to three hauls come back to port to sell the catch. Both sand eel species can appear mixed in the catch. By-catch is low and most of it can be released alive (Table 1). On a fishermen's initiative, the first regulatory framework specific for the fishery was adopted in 1987. A key element of this initial regulation was the implementation of a seasonal closure during the reproduction period (December 15 th to the end of February). Management measures adopted in recent years also include a closed census of authorized boats.

The sonsera gear can also be used, with some minor adaptations, to catch small gobies (Aphia minuta, Crystallogobius linearis and Pseudaphia ferreri). These species are fished on muddy or sandy-muddy bottoms, transparent goby (Aphia minuta) in the southern fishing grounds at 7-12 $\mathrm{m}$ depth and crystal goby (Crys-
Table 1. - By-catch of sand eel fishery, expressed as percentage in weight, according to two sources: logbooks (accounting for 843 tons of sand eel) and sampling (accounting for $9.6 \mathrm{t}$ of sand eel).

\begin{tabular}{lcc}
\hline Species or taxonomic group & Logbooks & Sampling \\
\hline Pagellus erythrinus & 0.053 & 0.347 \\
Xyrichtys novacula & 0.017 & 0.288 \\
Bothus podas & 0.011 & 0.252 \\
Spicara spp. & 0.081 & 0.230 \\
Synodus saurus & 0.011 & 0.216 \\
Mullus spp. & 0.001 & 0.091 \\
Trachinus draco & 0.026 & 0.057 \\
Scomber colias & 0.069 & 0.031 \\
Cephalopods & 0.005 & 0.030 \\
Seriola dumerilii & 0.010 & 0.028 \\
Citharus linguatula & 0.001 & 0.002 \\
Trachurus spp. & 0.026 & 0.000 \\
Sparus aurata & 0.001 & 0.000 \\
Rajidae & 0.001 & 0.000 \\
TOTAL & 0.313 & 1.573 \\
\hline
\end{tabular}

tallogobius linearis) in the northern fishing grounds at 30-50 $\mathrm{m}$ depth. Catches of Pseudaphia ferreri are negligible. Traditionally the fishing period for these species has been from November to May, partially overlapping with the sand eel closure.

European legislation (European Council 2006) explicitly prohibits the use of boat seines as being used currently in terms of mesh size, depth and distance from the coast, so the sonsera is automatically outside the law unless the corresponding derogations within the context of a comprehensive management plan are approved. The main issues in this process are the sustainability of sand eel stocks, by-catch prevention and seagrass meadow protection.

According to the OECD (1996), co-management is a process of management in which government shares power with resource users, with each given specific rights and responsibilities relating to information and decision-making. Much literature has been produced recently regarding fisheries co-management (e.g. Wilson et al. 2003, Pomeroy and Rivera-Guieb 2006, Pope 2009, Berkes 2009, Gutiérrez et al. 2011). Often comanagement is presented as related to the ecosystem approach to fisheries (FAO 2009). However, though fisheries co-management as a concept has a relatively short history, as a practice it has been present for a much longer period (Jentoft 2003) and is not completely new in the Mediterranean. A general review of assessment and management issues in Mediterranean and Black Sea has been done by Caddy (2009).

In 2012 a Sand Eel Co-Management Committee was appointed to carry out a scientific study that would support a management plan for the sonsera. It was also tasked with the management of the fishery during the initial interim period. That Committee is composed of the public administration, fishermen's associations, researchers and civil society represented by NGOs. An executive permanent committee with two representatives of each part meets monthly to monitor the fishery output, analyse incidents and take decisions. Fishermen play a major role in this structure so it can be considered as a fully co-management process sensu FAO (i.e. Halls et al. 2005), and included as a main issue of the ecosystem approach to fisheries (EAF) (FAO 2003, Garcia et al. 2003). 


\section{THE PROBLEM}

On 21 December 2006 the European Union adopted the Council Regulation (EC) No 1967/2006 (European Council 2006) concerning management measures for the sustainable exploitation of fishery resources in the Mediterranean Sea. Article 19 of the regulation provides for compulsory adoption of management plans by member states for fisheries conducted by boat seines (among other gears) no later than December 2007. The same regulation adopts technical measures related to mesh size (Article 9), and the minimum distance from the coast and depths allowed for towed nets, a category in which boat seines are included (Article 13). Transitional derogations until 31 May 2010 applied to the minimum mesh size and minimum distance from the coast for fishing gears operating in accordance with national law in force on 1 January 1994 (Article 14). Permanent derogations were conditional to a positive scientific study supporting the corresponding management plans.

On 11 May 2010 a first draft of the Management Plan for Artisanal Fishing with Boat Seines or Sonsera was submitted to the Spanish Government to be delivered to the European Commission. Several questions and answers regarding the improvement of the document went from and to the EC until January 2012, when the submitted plan was not accepted due to the lack of a scientific study that would support the proposed measures and derogations. Therefore, the fishery was deemed not legal and forced to close in March 2012, right after the annual closed season. This entailed a huge crisis in the sector, which approached the NGOs, scientists and the different administrations calling for support.

The main issues regarding the sustainability of boat seining are the following:

- The fishery of both the main target species (sand eel) and the minor one (transparent gobies) must be sustainable with respect to the target species.

- The activity of the sonsera must not be detrimental to vulnerable habitats, especially by avoiding fishing on seagrass meadows.

- The by-catch, if any, must be very low (i.e. up to $1 \%$ and no more than $5 \mathrm{~kg}$ ).

\section{THE CO-MANAGEMENT COMMITTEE}

During informal meetings among stakeholders held in March 2012, it was agreed to create a Sand Eel Co-Management Committee including fishermen, the fisheries administration, NGOs and scientists. The co-management committee was formally established on April 26, 2012. Fisheries authorities include both the central Spanish government authority (which joined the Committee in December 2012), and the Catalan government authority. NGOs include the World Wide Fund for Nature (WWF) and Greenpeace. A permanent committee composed of a sub-set of ten members (two per stakeholder) meets at least once a month; decisions are taken by consensus whenever possible and at least by a majority of seven votes. This scheme strengthens the sense of ownership of the management process among all stakeholders, resulting in a very high adherence to the rules.
The Sand Eel Co-Management Committee has both short term and long-term objectives. In the short term the aim of the Committee has been to design a new management plan based on a comprehensive scientific study and to manage the fishery during this interim period. In the long term, subject to approval of the management plan, the objective is to implement the plan, to control its implementation, to monitor the indicators, to adjust the fishing activity according to the harvest control rules and to decide on penalties in case of noncompliance.

The fishery was closed in March 2012, right after the start of the fishing season. To de-block the situation, in June 2012 the co-management committee obtained approval for a "scientific fishery" under highly strict and precautionary rules with the purpose of carrying out the scientific study needed to develop the management plan during the following 18 months. The plan, after approval by the authorities, would allow the reopening of the commercial fishery for the 2014 fishing season. The legal provisions allowing for the scientific fishery are specifically stated by invoking a Council Regulation (European Council 2009), whereby a Community fishing vessel shall be authorized "fishing for scientific purposes" only if "indicated in a valid fishing authorization" (Article 7). Moreover, the same regulation also allows for the commercialization of the catches when they are carried out for scientific purposes (Article 33). In addition, authorized fishing for scientific purposes is exempt from the obligation of compliance of the technical measures provided by the Mediterranean Regulation (European Council 2006), as clearly stated in its first article.

The management control rules for the sand eel fishery were based on standard methodologies and take into account the precautionary approach (Caddy 2009). They were stated as follows:

- Set a total allowable catch (TAC) for the sand eel fishing season. Since the Sand Eel Co-Management Committee was created in April 2012, the scientific study started in August, and the sand eel fishing season covers the period from 1 March to 15 December, the scientific study could not monitor a whole fishing season but two halves, covering a composite fishing season, from August 2012 to July 2013. Given the urgency it was not possible to wait until March 2013 to monitor one complete fishing season. The TAC was set at 819 t (i.e. 2012 landings). This figure was the highest value reported since 2000 although there is consensus that real catches have been much higher in recent years because underreporting is a widespread practice in this fishery.

- Set the fishing effort at ten boats per day for five days a week on all working days during the fishing season. This measure means an effort reduction of $40 \%$ in comparison with previous seasons, when 25 fishing boats were operating regularly. A rotating procedure was established in order to avoid unbalances.

- Determine fixed quotas per boat and day on two levels: boats with two persons onboard and with three persons onboard, the latter being larger than the former. These quotas were established at the beginning of the season (i.e. 500 and $660 \mathrm{~kg}$ ) but were reviewed 
monthly and modified as the cumulative catch of the entire fishery approached the TAC. The Sand Eel CoManagement Committee was very strict on that, and fishermen who exceed the quota must compensate it later. If the overcatch is over $10 \%$, the profits are allocated to social purposes.

- The whole commercial catch must be sold by official auction.

- Every boat owner must present a logbook every day accounting for every haul with the following data: fishing time, total catch (estimate percentage of species), by-catch, georeferenced position and depth. A total of 1906 daily trips and 3038 hauls were collected in the study period.

- Host technicians on board to collect samples. The sampling schedule included four monthly onboard samplings in different areas and boats. These operations were also performed during the closed season, in this case taking only specimens for scientific use.

- Other traditional rules were maintained: fishing seasons, obligation to fish in daylight, limited time at sea and technical characteristics of the gear.

\section{THE SCIENTIFIC STUDY}

The scientific study was mainly based on the data collected during the period August 2012 to July 2013. Previous information about the fishery in recent years was available but its reliability was doubtful. Nevertheless, these data were also scrutinized.

Data on first sale of fish catches in all ports of Catalonia have been available since 2000 and are provided by the Catalan government. Data consist of landings and revenues of fish sold by species, boat and day. This constitutes a huge amount of data (14 million records in the period 2000-2012), with sand eel a small part of the total $(0.2 \%)$

However these data involve many problems, especially when a fine analysis is required, as in the present case. Species misidentification and underreporting are the two main errors present in the database. Underreporting of sand eel in the historical series was the first problem to deal with. The cause of this bias was that catches were sold outside the official market.

Data collected specifically during the period August 2012 to July 2013 include i) close monitoring of catches per boat and day under the special fishing plan mentioned above, and ii) a sampling campaign carried out on board boat seiners (monthly, four fishing days) to obtain data on the specific composition of the total catch, length frequency distributions of target and bycatch species, length-weight measurements and, when possible, target species sex and maturity.

The scientific study dealt with different aspects of target species biology, boat seine fishing, impact on the habitat and population dynamics. The results include the following topics:

- Target species identification.

- Biological parameters: length-weight relationships, growth, maturity stages.

- Sand eel and small goby size distributions by area and time.
- Description of the gear, fishing operation and fleet behaviour.

- Fleet composition and characteristics.

- Mapping geographical distribution of hauls, depth and type of bottoms and comparison with the available information on seagrass habitats.

- Selectivity of the fishing gear.

- By-catch, species identification, sizes, amounts and release of live specimens.

- Population dynamics and stock assessment.

The figures resulting from these controls are presented and discussed monthly in the Sand Eel Co-Management Committee, and modifications and penalties are agreed.

The scientific study refers to the sonsera gear, although this gear has two different strategies targeting sand eels and small gobies.

\section{RESULTS OF THE SCIENTIFIC STUDY}

On the Catalan coast, the boat seine fishery is driven by the Mediterranean sand eel (Gymnammodytes cicerelus), with catches of smooth sand eel (Gymnammodytes semisquamatus) representing only around $2 \%$ of the total. Landings and activity of the boat seine fleet targeting gobid species, transparent goby Aphia minuta and crystal goby Crystallogobius linearis, are low in comparison with those of the fleet targeting Mediterranean sand eel. Only two specimens of Pseudaphya ferreri were observed.

The boat seine fishing gear is used exclusively for fishing sand eel and gobid species. The sand eel fishing grounds are located very close to the coast (depending on the zone, within 400-600 $\mathrm{m}$ from the coast), in shallow waters (6-16 m depth, occasionally up to $30 \mathrm{~m}$ in the north of the area). Gobid species are fished on muddy or sandy-muddy bottoms: transparent goby at 7-12 m depths in the southern fishing grounds and depth crystal goby at 30-50 $\mathrm{m}$ in the northern fishing grounds.

Four species of seagrass have been reported in Catalan coastal waters (Romero et al. 1995, Barba et al. 2011): Zostera marina, Zostera noltii, Cymodocea nodosa and Posidonia oceanica. The species of the Zostera genus do not grow beyond $10 \mathrm{~m}$ depth, $C$. nodosa and $P$. oceanica inhabit a depth range between 10 and $40 \mathrm{~m}$ and Posidonia oceanica is by far the most abundant. The Catalan government monitors seagrass meadows along the coast and has published a map (Anon. 2001). Updated and improved information (2012-2013) was provided by the Catalan government to the scientific partner of the Sand Eel Co-Management Committee.

Sand eel has not been reported to occur in seagrass meadows (Pergent et al. 2012) because the species actually inhabits sandy bottoms. However, the possible impact of sand eel fishery on seagrass meadows is a major issue regarding the potential effect of the fishery on marine ecosystems. A representation of both seagrass meadows and individual hauls was made using Google Earth. By plotting haul positions against seagrass distribution maps, it can be concluded that the sonsera is not used on sea bottoms characterized by the 
presence of seagrass meadows, in particular Posidonia oceanica.

The analysis of the boat seine catch when targeting sand eel evidenced the high selectivity of the sonsera, as the presence of by-catch species can be detected by the echo-sounder, which allows selective fishing operations resulting in catches without or with very few non-target species. The percentage in weight of by-catch species regarding the total sand eel catch was very low over the study period, around $2 \%$ to $3 \%$.

In the gobid fishery, the presence of by-catch species is also detected by echo-sounder to improve the selectivity of the fishing operation. The two gobid species are very small and have a very low weight. Therefore, the weight ratio between these species and the by-catch species showed a different picture from the one shown in the case of the sand eel. In Aphia minuta catches represented $61 \mathrm{~kg}$ of transparent goby against $17.86 \mathrm{~kg}$ of by-catch, that is $29.3 \%$, mainly Mullus barbatus, Pagellus erythrinus, Trachurus spp. and Sardina pilchardus. For Crystallogobius linearis the relationship was $87.60 \mathrm{~kg}$ of crystal goby against $139.95 \mathrm{~kg}$ of by-catch (160\%), the main by-catch species being Mullus barbatus, Pagellus erythrinus, Diplodus annularis, Allotheuthis media, Octopus vulgaris, Loligo vulgaris and Sardinella aurita.

It is important to note that the by-catch species analysed would have been released at sea alive if they had not been retained for study. No data on post-capture mortality were obtained, but field observation show normal swimming behaviour of the released animals. Commercialization of by-catch species was forbidden during the scientific study as in the case of sand eel.

This study has provided information on the main biological traits of the Mediterranean sand eel (distribution, growth, reproduction period, size-at-first maturity, and timing of recruitment). The biology of $G$. cicerelus and $G$. semisquamatus in the study area was unknown, except for scattered information reporting the presence of larvae at certain times of the year.

According to the assessment scenarios considered, it appears that the sand eel fishery studied during the period August 2012 to July 2013 through length-based pseudocohort analysis appears to be in a healthy state. Only in the worst parameter combination could a slight growth in overfishing appear but no traces of recruitment overfishing were detected. In 2013, the boat seiners had no difficulty in obtaining the monthly quotas to reach $819 \mathrm{t}$ by the end of the fishing season, which would suggest that sand eel abundance did not decrease in comparison with 2012. For 2014 a quota of $819 \mathrm{t}$ is proposed, as in 2012 and 2013.

The reproduction period of Gimnammodytes cicerelus in the area extends from November to February and at the end of the fishing season, in mid-December, the population consists of individuals that have attained the size-at-first-maturity. Most of individuals caught belong to 0-class.

Transparent goby (Aphia minuta) and crystal goby (Crystallogobius linearis) landings over the fishing seasons (from November to May) 2001-2003 to 20122013 displayed marked fluctuations. In addition, the landings pattern within each fishing season was also very variable, the landings peak in each season occurring in different months. The monthly landings and catch per unit effort (CPUE) trend in some of the fishing seasons, which increased after decreasing, suggest the incorporation of new individuals after the start of the fishing season, which prevents the use of depletion methods. Available data do not allow reliable assessments. The highest CPUEs were not obtained at the beginning of the fishing season, which suggests that the onset of the fishing season is not coincidental with the massive incorporation of recruits, unlike what happens to sand eels.

Historically a very limited number of boats (four to six) targeted gobids. When the new management plan comes into force, only six seiners will be able to go fishing gobids.

\section{ADVICE}

Regarding the protection of seagrass meadows, although sand eel does not inhabit them, after updating the cartography of the seagrass habitat it would be sensible to create a protection buffer area around them. Taking into consideration the control measures to avoid the commercialization of by-catch species and the good results regarding gear selectivity and the live release of by-catch species, it is recommended to limit the by-catch species to a maximum weight percentage of $1 \%$ of the total catch or less than $5 \mathrm{~kg}$ of total weight. Furthermore, by-catch species commercialization must remain forbidden.

It is advisable to maintain the fishing limitations applied during the study, for which an effort reduction to a half and a TAC was established. Furthermore, monthly harvest control rules to keep the fishery under continuous observation is highly recommended. If a plan for the management of the sand eel fishery is approved in the coming years, the fishing season quota will be set at the start of the season and based on the results of the previous fishing season.

Given the reproductive season of Gymnammodytes cicerelus and since the yield at the start of the fishing season has been shown to be related to the yield at the end of the previous fishing season (Spawning StockBiomass - Recruitment relationship), it is advisable not to modify the current closed-season period from 16 December to the end of February. Given the poor data available on small gobies, it is proposed for 2014 to set the historical average catch over 2001-2013 as a TAC, which provides an estimate of 1.8 tons of Aphia minuta and 3.8 tons of Crystallogobius linearis.

\section{CONCLUSIONS AND FUTURE}

In this first phase of the co-management operation, no studies on the ecological role of sand eel have been performed other than the impact on sensitive bottoms and by-catch. Sand eel can be considered as a forage species. According to recent ecological studies forage fish are of paramount interest to the functioning of marine ecosystems (Pikitch et al. 2012, Ahrens et al. 
2012). Cury et al. (2011) propose the reference point of "one third [of virgin forage species biomass] for the birds". Based on nine case studies including sand eel in the North Sea, Pikitch et al. (2012) propose keeping biomass above $80 \%$ the virgin level in data-poor forage fish fisheries. Contrasting with other forage fish species in the global ocean, Gymnammodytes cicerelus in the Mediterranean is restricted to a very narrow coastal fringe and sand eel accounts for only about $6 \%$ of the catch of all forage species (mainly sardine and anchovy) in Catalonia. Lacking specific studies, it can be hypothesized that the relevance of the species in the channeling of the trophic energy of the overall marine ecosystem towards upper trophic levels is limited and mainly localized. Detailed studies are needed to test this assumption.

A sustainable fishing of sand eel is likely if it is monitored and controlled adequately. In a ranking of the main threats to the sustainability of fisheries in Catalonia the sonsera should be placed in a very low position, clearly below bottom trawl and purse seiners.

Co-management means a step towards the rational management of fisheries in the Mediterranean. Paradoxically, this devolution of management powers can be understood as the contemporary adaptation of ancient customary schemes successfully regulating activities on fishing commons. The Catalan Sand Eel Co-Management Committee brings a participative, bottom-up approach to the management of fisheries. The strong point and most advanced aspect of the Committee is that all participants are on an equal footing for decision-making regarding the setting of rules and their implementation.

Co-management is not completely unknown in NW Mediterranean fisheries: in particular, an attempt to manage trawl fisheries during the 1960s was successful for five years in Castelló, Spain (Lostado et al. 1999). This project failed owing to the lack of continuity of the commission in charge of its implementation, offering an important lesson for similar contemporary experiences. In 2011 a co-management committee for the management of Aphia minuta fishery in Toscana and Liguria was officially established through a ministerial decree (Abella com. pers.)

After the formal approval of the management plan from the European Commission, the Sand Eel Co-Management Committee will continue a close follow-up and monitoring of the fishery. The scientific monitoring will also support compliance with the European legislation requirement of revising management measures affecting short-life species such as the sand eel annually. The commitment for financial support by fishermen is essential to guarantee the continuity of the Committee's activities and therefore the long-term sustainability of the fishery.

\section{ACKNOWLEDGEMENTS}

The scientific study was supported by fishermen, including the costs of sampling (presence of sampling personnel on board, no income for the fish used for scientific study). The other co-management partners contributed in-kind resources such as personnel and infrastructure. The field and laboratory work of Ana Isabel Colmenero, Alfredo Garcia de Vinuesa and Elia Vallejo is acknowledged. The authors wish to acknowledge the excellent collaboration among all members of the co-management committee. In particular we wish to mention its originator, Mercè Santmartí, former Director General of Fisheries and Maritime Affairs of the Catalan government and the two fishermen of the permanent committee, Mauricio Pulido and Lluís Trias. The Sand Eel Co-Management Committee received the WWF Award for Conservation Merit in 2013.

\section{REFERENCES}

Ahrens R.N.M, Walters C.J., Christensen V. 2012. Foraging arena theory. Fish Fish. 13: 41-59. http://dx.doi.org/10.1111/j.1467-2979.2011.00432.x

Anon. 2001. Les fanerògames marines de la costa catalana. Direcció General de Pesca i Afers Marítims, Departament d'Agricultura Ramaderia i Pesca, Generalitat de Catalunya, 50 pp.

Anon. 2002 (estimated date). Strategic Action Plan for the Conservation of Biological Diversity in the Mediterranean Region (SAP BIO) Spanish National report, $107 \mathrm{pp}$.

Barba C. 2011. Béns i serveis associats als ecosistemes de fanerògames marines i estimacions de pèrdues causades per la seva degradació. Facultat de Ciències Secció de Ciències Ambientals. Universitat Autònoma de Barcelona, 74 pp.

Bas C., Morales E., Rubió M. 1955. La Pesca en España, I Cataluña. Instituto de Investigaciones Pesqueras, CSIC, 468 pp.

Berkes F. 2009. Social aspects of fisheries management. In: Cochrane, K.L. and S.M. Garcia (eds), A fishery manager's guidebook, 2nd edition. Wiley-Blackwell and FAO. 518 pp. $52-74$.

Bomare V. 1764. Dictionnaire raisonné universel d'hisoire naturelle. Paris, 5 vols.

Bomare V. 1800. Dictionnaire raisonné universel d'hisoire naturelle. Lyon, 15 vols

Borja y Goyeneche J. 1920. Contribución al estudio de la fauna ictiológica de España. Mem. Real Acad. Cienc. Art. Barcelona, Tercera época 16(3): 191-299.

Caddy J.F. 2009. Practical issues in choosing a framework for resource assessment and management of Mediterranean and Black Sea fisheries. Mediterr. Mar. Sci. 10(1): 83-119.

Cury P.M., Boyd I.L., Bonhommeau S., Anker-Nilssen T., Crawford R.J.M., Furness R.W., Mills J.A., Murphy E.J., Österblom H., Paleczny M., Piatt J.F., Roux J.-P., Shannon L., Sydeman W.J. 2011. Global Seabird Response to Forage Fish Depletion-One-Third for the Birds. Science 334(6063): 1703-1706. http://dx.doi.org/10.1126/science.1212928

Delaroche F.E. 1809. Observations sur des poissons recueillis dans un voyage aux îles Baléares. Anal. Mus. Hist. Nat. Tome Treizième, Paris. 313-361 plus 25 planches

European Council. 2006. Council Regulation (EC) No 1967/2006 of 21 December 2006

European Council. 2009. Council Regulation (EC) No 1224/2009 of 20 November 2009

FAO. 2003. The ecosystem approach to fisheries. FAO Tech. Guid. Resp. Fish. No. 4, Suppl. 2, Rome, 112 pp.

FAO. 2009. Fisheries management. 2. The ecosystem approach to fisheries. 2.2 Human dimensions of the ecosystem approach to fisheries. FAO Tech. Guid. Resp. Fish. No. 4, Suppl. 2, Add. 2. Rome, 88 pp.

Fischer W., Schneider M., Bauchot M.-L. 1987. Fiches FAO d'identification des espèces pour les besoins de la pêche. Meditérranée et Mer Noire. Zone de Pêche 37. Révision 1. Volume 1: Vegetaux et Invertebrées, Volume 2: Vertebrées. Rome, 1529 pp.

Garcia S.M., Zerbi A., Aliaume C., Do Chi T., Lasserre G. 2003. The ecosystem approach to fisheries. Issues, terminology, principles, institutional foundations, implementation and outlook. FAO Fish. Techn. Pap. 443, 71 pp.

Gibert J. 1913. Fauna ictiològica de Catalunya. Imp. J. Bartra Laborde. Barcelona, 96+XI pp.

Gutiérrez N.L., Hilborn R., Defeo O. 2011. Leadership, social capital incentives promote successful fisheries. Nature 470: 386-389. 
http://dx.doi.org/10.1038/nature09689

Halls A.S., Arthur R.I., Bartley D., Felsing M., Grainger R., Hartmann W., Lamberts D., Purvis J., Sultana P., Thompson P., Walmsley S. 2005. Guidelines for designing data collection and sharing systems for co-managed fisheries. Part 1: Practical guide. FAO Fish. Techn. Pap. 494/1. Rome, 42 pp.

Jentoft S. 2003. Co-management. The way forward. In: Wilson, D.C, Nielsen J.R., Degnbol P. (eds) 2003. The fisheries comanagement experience: accomplishments, challenges and prospects. Fish Fish., Ser. 26, xix, 324: 1-14

Lleó J.M. 1923. "Costas de Cataluña", in: La pesca marítima en España en 1920. Ministerio de Marina, Dirección General de Navegación y Pesca Marítima, Inspección de Estudios Científicos y Estadísticos de Pesca, Madrid, 2 vols. Vol 1: 91-183+XVI plates.

Lleonart J. (Coord.) 1990. La pesquería de Cataluña y Valencia: descripción global y planteamiento de bases para su seguimiento. Informe Final de la III fase del proyecto. Comisión de las Comunidades Europeas. Dirección General XIV (Pesca) $n^{\circ}$ 1989/3. 1634 pp. (mimeo).

Lostado R., del Río V., Vivas D. 1999. The Castellón trawling project (1961-1966): teachings for a sustainable fisheries management. Informes y Estudios COPEMED. $\mathrm{N}^{\mathrm{o}} 2,170 \mathrm{pp}$.

Nelson J.S. 2006. Fishes of the World. Wiley \& Sons Inc. 4th edition, $601 \mathrm{pp}$.

OECD. 1996. Synthesis report for the study on the economic aspects of the management of marine living resources. AGR/FI(96)12.

Pergent G., Bazairi H., Bianchi C.N., Boudouresque C.F., Buia M.C., Clabaut P., Harmelin-Vivien M., Mateo M.A., Montefalcone M., Morri C., Orfanidis S., Pergent-Martini C., Semroud R., Serrano O., Verlaque M. 2012. Mediterranean Seagrass Meadows: Resilience and Contribution to Climate Change Mitigation, A Short Summary / Les herbiers de Magnoliophytes marines de Méditerranée : résilience et contribution à l'atténuation des changements climatiques, Résumé. Gland, Switzerland and Málaga, Spain: IUCN. 40 pages.
Pikitch E, Rountos K. J., Essington T.E., Santora C., Pauly D., Watson R., Sumaila U.R., Boersma P.D., Boyd I.L., Conover D.O., Cury P., Heppell S.S., Houde E.D., Mangel M., Plagányi É., Sainsbury K., Steneck R.S., Geers T.M., Gownaris N., Munch S.B. 2012 The global contribution of forage fish to marine fisheries and ecosystems. Fish Fish. 15(1): 43-64 http://dx.doi.org/10.1111/faf.12004

Pomeroy R.S., Rivera-Guieb R. 2006. Fishery co-management: a practical handbook. CAB International $i$ association with International Development Research Centre. Ottawa. Canada. 264 p. http://idl-bnc.idrc.ca/dspace/bitstream/10625/29766/21/121681.pdf

Pope J.G. 2009. Input and output controls: the practice of fishing effort and catch management in responsible fisheries. In: Cochrane, K.L., Garcia S.M. (eds), A fishery manager's guidebook, 2nd edition. Wiley-Blackwell and FAO, pp. 220-252.

Reay P.J. 1970. Synopsis of biological data on North Atlantic sandeels of the genus Ammodytes (A. tobianus, A. dubius, A. americenus and $A$. marinus) FAO Fish. Synops. (82): 48 pp.

Romero J., Corbera J., Fernández Gras M. 1995. Els boscos del fons del mar. Direcció General de Pesca Marítima, Departament d'Agricultura, Ramaderia i Pesca, Generalitat de Catalunya. 33 pp.

Sabatés A., Demestre M., Sánchez P. 1990. Revision of the familiy Ammodytidae (Perciformes) in the Mediterranean with the first record of Gymnammodytes semisquamatus. J. Mar. Biol. Ass. UK, 70:493-504. http://dx.doi.org/10.1017/S0025315400036535

Sánchez P., Demestre M. 1988. Note préliminaire concernant la pêche de Gymnammodytes cicerelus en Catalogne (NE de l'Espagne). Rapp. Comm. Int. Mer Medit. 31(2) V-II 45: 279.

Sánchez-Comendador A. 1904. Catalech dels peixos observats en el litoral de Barcelona, Butll. Inst. Cat. Hist. Nat. $2^{a}$ època. 1-2: 25-32.

Wilson D.C, Nielsen J.R., Degnbol P. (eds) 2003. The fisheries co-management experience: accomplishments, challenges and prospects. Fish Fish., Ser. 26, xix, 324 pp. 